\title{
Pregnancy does not affect fecal calprotectin concentration in healthy women
}

\author{
Anita Bálint', Anna Berényi', Klaudia Farkas', Éva Pallagi-Kunstár', Ábel Altorjay², Andrea Csonka², \\ Mária Krizsán", Mónika Szücs", Attila Pál', Anna Fábián', Renáta Bor', Ágnes Milassin', Ádám Szulcsán', \\ Rutka Mariann', Zoltán Szepes', Tamás Molnár \\ 'Department of Medicine, University of Szeged, Szeged, Hungary \\ ${ }^{2}$ Department of Obstetrics and Gynecology, University of Szeged, Szeged, Hungary \\ ${ }^{3}$ Kaáli Institute, Szeged, Hungary \\ ${ }^{4}$ Department of Medical Physics and Informatics, University of Szeged, Hungary
}

\begin{abstract}
Background/Aims: Noninvasive activity markers are extremely important in conditions, such as pregnancy, when endoscopy is not recommended. The aim of this prospective study was to determine fecal calprotectin (FC) concentrations in healthy non-pregnant and pregnant women and in patients with inflammatory bowel disease (IBD).

Materials and Methods: Healthy pregnant and non-pregnant women and patients with active and inactive IBD were prospectively enrolled in this study. Demographic and clinical parameters and clinical disease activity scores in patients with IBD were recorded. Blood and stool samples of every patient were obtained to determine C-reactive protein and FC levels. FC levels were measured with a quantitative lateral flow assay.

Results: One hundred and thirty-five subjects were enrolled in the study (24 non-pregnant and 48 pregnant healthy women, 40 non-pregnant patients with active IBD and 23 non-pregnant patients with inactive IBD). FC was significantly higher in active IBD patients than in pregnant $(p<0.001)$ and non-pregnant healthy women $(p<0.001)$. No difference could be detected in FC concentrations between pregnant and non-pregnant healthy women.

Conclusion: Since FC levels remained unchanged during pregnancy, it may be a useful noninvasive diagnostic tool in pregnancy for monitoring mucosal inflammation.
\end{abstract}

Keywords: Fecal calprotectin, pregnancy, inflammatory bowel disease, Crohn's disease, ulcerative colitis, Creactive protein

\section{INTRODUCTION}

Numerous physiological changes occur during pregnancy, some of which can induce significant alterations in serum laboratory values. Common examples are lower hematocrit and hemoglobin concentrations, but the level of several inflammatory markers that correlate with the activity of inflammatory bowel disease (IBD) in nonpregnant patients can also increase during pregnancy. To date, no optimal activity marker exists to assess the activity of IBD during pregnancy. The role of fecal calprotectin (FC) is conflicting in pregnant women, although it correlates well with different inflammatory processes of the gastrointestinal tract, suggesting FC to be a useful tool in these patients with highly limited diagnostic procedures.
FC also correlates with the endoscopic and histological grading of disease activity in IBD and is a good predictor for future relapse in these patients (1). Calprotectin is associated with many systems, disorders, and physiological processes including pregnancy. The production of S100A8 is elevated in cytotrophoblasts, placental-tissue macrophages, fibroblast-like cells, endothelial cells, and monocytic lineages. In fetal capillaries, the highest level can be detected during the first and second trimesters of pregnancy in the placenta (2). Increased levels of calprotectin in the amniotic fluid are related with intra-amniotic inflammation and a shorter interval to parturition (3). However, the influence of pregnancy on FC level in healthy pregnant women has not yet been examined. 
Noninvasive activity markers for the evaluation of disease activity in pregnant women suffering from IBD in whom endoscopy should not be performed would have significant clinical relevance. However, as there are no data available on the changes in FC during normal pregnancy, we aimed to assess FC concentration in healthy pregnant and non-pregnant women.

\section{MATERIALS AND METHODS}

Between January 2013 and January 2016, 24 healthy women [controls without any bowel disease and women undergoing in vitro fertilization cycles (mean age: 33.1 years, SD: 5.2 years)], 48 healthy pregnant women (pregnant subjects without any bowel disease; mean: 35.9 years, SD: 5.2 years) were enrolled in this prospective study. The second control group consisted of 40 women with active IBD (mean: 39.6 years, SD: 15 years) and 23 women with IBD in sustained clinical remission (mean: 42.0 years, SD: 13.9 years) (Table 1). The clinical activity of IBD was assessed with partial Mayo (pMayo) $(4,5)$ score in ulcerative colitis (UC) patients and with Crohn's Disease Activity Index (CDAl) in Crohn's disease (CD) patients. Endoscopy was excluded from the full Mayo score. FC and serum C-reactive protein (CRP) measurements were performed in all participants to assess the effect of pregnancy on FC concentrations and CRP levels. Stool samples were collected from the first bowel movement in the morning. Fecal samples for FC determination were stored at $-20^{\circ} \mathrm{C}$ until analysis. Fecal specimens were thawed and prepared for FC assay as described by the manufacturer. FC concentrations were measured with a quantitative lateral flow assay (Quantum Blue, Bühlmann Laboratories, Switzerland).

\section{Statistical Analysis}

Statistical analyses were performed using R statistical program (version 3.2.4). Descriptive parameters were shown as mean (SD) and/or median (range). The Mann-Whitney $U$ test and Kruskal-Wallis test followed by post-hoc tests were used to analyze FC concentrations and CRP levels within groups. The post-hoc pairwise comparisons (if required) were performed according to the Bonferroni-Holm method. A p value of $<0.05$ was considered statistically significant.

\section{Ethics}

The study was approved by the Regional and Institutional Human Medical Biological Research Ethics Committee of the University of Szeged (ethical approval number: SZTE-170/2011). The study conforms to the declaration of Helsinki. All study participants, or their legal guardian, provided written informed consent prior to study enrolment.

\section{RESULTS}

\section{Healthy Female Controls without IBD}

The mean FC concentration was $34.1 \mu \mathrm{g} / \mathrm{g}$ (median: : $25 \mu \mathrm{g} / \mathrm{g}$, SD: $27.5 \mu \mathrm{g} / \mathrm{g}$, range: $25.0-150.0 \mu \mathrm{g} / \mathrm{g}$ ) in healthy controls. In healthy controls, we found five patients with gynecological diseases (endometriosis, myoma uteri, and PCOS), two patients with hypothyreosis, one with hypertonia, and one with pancreas divisum. A significant difference $(p<0.001)$ in FC concentrations was shown between

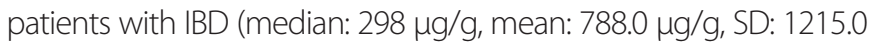

Table 1. Summary of age, FC concentration, and CRP level in healthy controls, healthy pregnant subjects, patients with active IBD, and patients with inactive IBD

\begin{tabular}{|c|c|c|c|c|}
\hline $\begin{array}{l}\text { Enrolled } \\
\text { subjects }\end{array}$ & $\begin{array}{l}\text { Healthy } \\
\text { non- } \\
\text { pregnant } \\
\text { women } \\
n=24\end{array}$ & $\begin{array}{c}\text { Healthy } \\
\text { pregnant } \\
\text { women } \\
n=48\end{array}$ & $\begin{array}{l}\text { Patients } \\
\text { with } \\
\text { active } \\
\text { IBD } \\
n=40\end{array}$ & $\begin{array}{l}\text { Patients } \\
\text { with } \\
\text { inactive } \\
\text { IBD } \\
n=23\end{array}$ \\
\hline Mean age $( \pm S D)$, years & $53.1(5.2)$ & $35.9(5.2)$ & $39.6(15.0)$ & $42.0(13.9)$ \\
\hline Mean FC ( $\pm S D$, ug/g) & $34.1(27.5)$ & $36.9(20.4)$ & $1146.5(1411.1)$ & $179.3(187.2)$ \\
\hline Mean CRP ( \pm SD, mg/l) & $4.3(3.9)$ & $6.0(4)$ & $13.4(16.1)$ & $8.8(17.2)$ \\
\hline
\end{tabular}

Table 2. FC and serum CRP levels during pregnancy

\begin{tabular}{lcccc}
\hline $\begin{array}{l}\text { No. of } \\
\text { subjects }\end{array}$ & $\begin{array}{c}\mathbf{1}^{\text {st }} \\
\text { trimester } \\
\mathbf{n = 2 0}\end{array}$ & $\begin{array}{c}\mathbf{2}^{\text {nd }} \\
\text { trimester } \\
\mathbf{n = 1 1}\end{array}$ & $\begin{array}{c}\mathbf{3}^{\text {rd }} \\
\text { trimester } \\
\mathbf{n = 2 7}\end{array}$ & $\Sigma$ \\
\hline FC level (ug/g) & 32.5 & 30.4 & 43.6 & 36.9 \\
Mean & 25 & 25 & 30 & 25 \\
Median & 20.4 & 9.9 & 31.5 & 20.4 \\
SD & $25-106$ & $25-52$ & $25-3000$ & $25-3000$ \\
Range & & & & \\
CRP (mg/L) & 6.6 & 4.6 & 5.0 & 6.0 \\
Mean & 5.8 & 1.8 & 3.6 & 4.0 \\
SD & $1-16.7$ & $2.4-7.9$ & $1-12.8$ & $1-16.7$ \\
Range & & & & \\
\hline FC: fecal calprotectin; CRP: C-reactive protein; SD: standard deviation & \\
\hline
\end{tabular}

$\mu \mathrm{g} / \mathrm{g}$, range: $25.0-5000.0 \mu \mathrm{g} / \mathrm{g}$ ) and healthy controls (median: 25 $\mu \mathrm{g} / \mathrm{g}$, mean: $36.0 \mu \mathrm{g} / \mathrm{g}$, SD: $23.0 \mu \mathrm{g} / \mathrm{g}$, range: 25.0-3000.0 $\mu \mathrm{g} / \mathrm{g}$ ).

\section{Pregnant Subjects}

In the pregnant subpopulation, 20 samples were from women in their first trimester, 11 samples were from women in the second, and 27 samples were from women in the third. Stool samples were collected from 10 of 48 pregnant subjects in the first, second, and third trimester. Ten gemini gravidities, two Rh-incompatibilities, and four other obstetric disorders were observed. In the pregnant group, four subjects had hypothyreosis, five had diabetes mellitus, three had hypertension, one had asthma, and one had hypercholesterinemia. With regard to FC concentration, healthy controls and pregnant subjects with the abovementioned diseases (me-

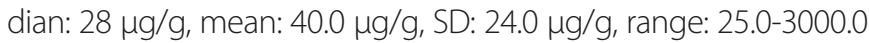
$\mu \mathrm{g} / \mathrm{g}$ ) were compared with healthy controls and pregnant patients without any disease (median: $25 \mu \mathrm{g} / \mathrm{g}$; mean: $34.0 \mu \mathrm{g} / \mathrm{g}$; SD: $23.0 \mu \mathrm{g} / \mathrm{g}$, range: $25.0-150.0 \mu \mathrm{g} / \mathrm{g}$ ), and no significant difference was observed. Mean FC concentration was $32.5 \mathrm{\mu g} / \mathrm{g}$ (median: 25 $\mu \mathrm{g} / \mathrm{g}$, SD: $20.4 \mu \mathrm{g} / \mathrm{g}$, range: $25.0-106.0 \mu \mathrm{g} / \mathrm{g}$ ) in women in the first trimester, $30.4 \mu \mathrm{g} / \mathrm{g}$ (median: $25 \mu \mathrm{g} / \mathrm{g}$, SD: $9.9 \mu \mathrm{g} / \mathrm{g}$, range: $25.0-$ $52.0 \mathrm{\mu g} / \mathrm{g}$ ) in the second trimester, $43.6 \mathrm{\mu g} / \mathrm{g}$ (median: $30 \mathrm{\mu g} / \mathrm{g}, \mathrm{SD}$ : $31.5 \mu \mathrm{g} / \mathrm{g}$, range: $25.0-138.0 \mathrm{\mu g} / \mathrm{g}$ ) in the third trimester (Table 2). We did not find significant difference $(p<0.092)$ between FC con- 


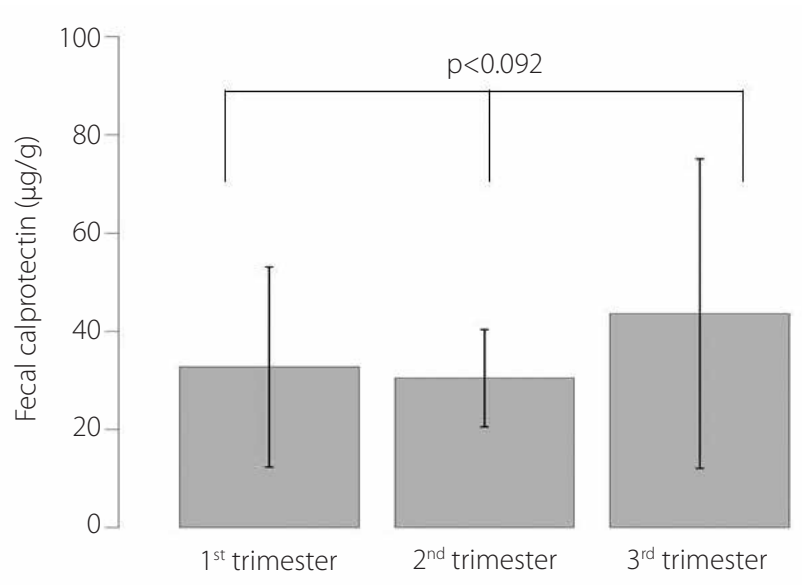

Figure 1. Bar chart with mean (SD) value. No significant difference $(p<0.092)$ was found between $F C$ levels in different trimesters during pregnancy

FC: fecal calprotectin

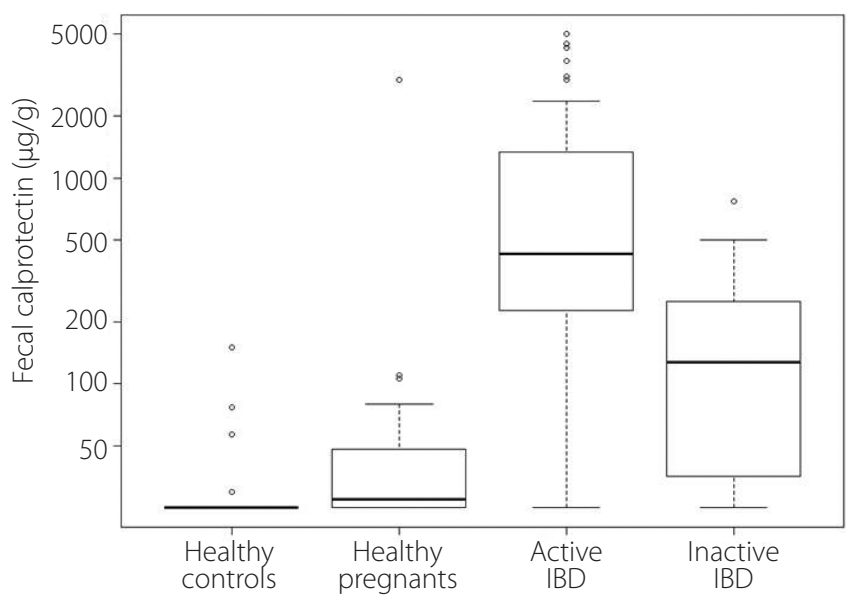

Figure 2. Boxplot with median, quartiles and min-max values of FC levels in assessed groups. FC was significantly higher in active IBD compared with pregnant $(p<0.001)$ and non-pregnant healthy women $(p<0.001)$ FC: fecal calprotectin; IBD: inflammatory bowel disease

centrations in different trimesters during pregnancy (Figure 1). Overall, the mean FC concentration was $36.9 \mu \mathrm{g} / \mathrm{g}$ (median: 25 $\mu \mathrm{g} / \mathrm{g}$, SD: $20.4 \mu \mathrm{g} / \mathrm{g}$, range: $25.0-3000 \mu \mathrm{g} / \mathrm{g}$ ) in pregnant women and did not differ significantly from that of non-pregnant healthy women $(p=0.99$ ). One gemini pregnant woman without IBD had outstandingly high FC concentration (3000 ug/g). She was diagnosed with Rh-incompatibilities (mother: A Rh-negative, "A fetus": AB Rh-negative, "B fetus": A Rh-positive); in addition, she had type I diabetes mellitus. After delivery, we could not follow her up.

\section{Female Patients with IBD}

Among IBD patients, 36 had CD and 27 UC. The majority of patients ( $n=54$ ) were under treatment at the time of study enrolment (Table 3). Eight active and one inactive IBD patients did not undergo therapy; however, these active IBD patients were previously in remission and came to consultation due to flare-up of symptoms. The mean CDAl was 211.7 points (SD: 73.5 points) in active CD and 87 points (SD: 26.7 points) in inactive CD. The mean pMayo subscore
Table 3. Treatment of IBD patients. Majority of the patients were under therapy at the time of enrollment

\begin{tabular}{lcccc}
\hline $\begin{array}{l}\text { No. of } \\
\text { subjects }\end{array}$ & $\begin{array}{c}\text { Active IBD } \\
(\mathbf{n}=\mathbf{4 0})\end{array}$ & $\begin{array}{c}\text { Inactive IBD } \\
(\mathbf{n}=\mathbf{2 3})\end{array}$ & $\begin{array}{c}\text { CD patients } \\
(\mathbf{n}=\mathbf{3 6})\end{array}$ & $\begin{array}{c}\text { UC patients } \\
(\mathbf{n}=\mathbf{2 7})\end{array}$ \\
\hline No therapy & 8 & 1 & 3 & 6 \\
Aminosalicylates & 13 & 6 & 7 & 12 \\
Corticosteroids & 6 & 0 & 5 & 1 \\
Thiopurines & 17 & 8 & 19 & 6 \\
Anti-TNF agents & 8 & 8 & 14 & 2 \\
Antibiotics & 1 & 1 & 2 & 0 \\
Topical therapy & 4 & 5 & 4 & 5 \\
\hline
\end{tabular}

IBD: inflammatory bowel disease; CD: Crohn's disease; UC: ulcerative colitis

was 4.6 points (SD: 2.0 points) and 0.8 points (SD: 0.8 points) in active and inactive $U C$, respectively. In patients with active IBD, mean

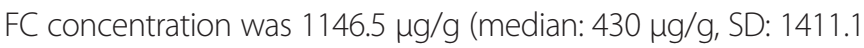
$\mu \mathrm{g} / \mathrm{g}$, range: $25.0-5000.0 \mu \mathrm{g} / \mathrm{g}$ ), whereas in patients in clinical remission, it was $179.3 \mu \mathrm{g} / \mathrm{g}$ (median: $127 \mu \mathrm{g} / \mathrm{g}$, SD: $187.2 \mu \mathrm{g} / \mathrm{g}$, range: 25.0-770.0 $\mu \mathrm{g} / \mathrm{g})(\mathrm{p}<0.001)$. The mean FC concentration was 592.0

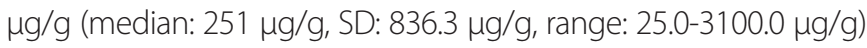
in CD and $1041.5 \mu \mathrm{g} / \mathrm{g}$ (median: $300 \mu \mathrm{g} / \mathrm{g}$, SD: $1558.0 \mu \mathrm{g} / \mathrm{g}$, range: 25.0-5000.0 $\mu \mathrm{g} / \mathrm{g}$ ) in UC patients. Among relapsed CD patients, the mean FC concentration was $877.9 \mu \mathrm{g} / \mathrm{g}$ (median: $500 \mu \mathrm{g} / \mathrm{g}$, SD: $1007.7 \mathrm{\mu g} / \mathrm{g}$, range: $25.0-3100.0 \mathrm{\mu g} / \mathrm{g}$, whereas in patients in remission, it was $210.7 \mu \mathrm{g} / \mathrm{g}$ (median: $148 \mu \mathrm{g} / \mathrm{g}$, SD: $218.7 \mu \mathrm{g} / \mathrm{g}$, range: 25.0-770.0 $\mu \mathrm{g} / \mathrm{g}$ ). The mean FC was $1429.3 \mu \mathrm{g} / \mathrm{g}$ (median: $430 \mu \mathrm{g} / \mathrm{g}$, SD: $1722.6 \mu \mathrm{g} / \mathrm{g}$, range: $25.0-5000.0 \mu \mathrm{g} / \mathrm{g}$ ) and $120.5 \mu \mathrm{g} / \mathrm{g}$ (median: $108.5 \mu \mathrm{g} / \mathrm{g}$, SD: $91.3 \mu \mathrm{g} / \mathrm{g}$, range: $25.0-300.0 \mu \mathrm{g} / \mathrm{g}$ ) in active and inactive UC patients, respectively. FC concentration was signifcantly higher in active IBD patients than in pregnant $(p<0.001)$ and non-pregnant healthy women $(p<0.001)$. Our results showed no significant difference between FC concentrations of inactive IBD patients and healthy controls $(p=0.99)$. Furthermore, no significant difference was revealed between FC concentrations of inactive IBD patients and pregnant women $(p=0.99)$.

\section{CRP in Assessed Subgroups}

Mean CRP levels were $6.6 \mathrm{mg} / \mathrm{L}$ (SD: $5.8 \mathrm{mg} / \mathrm{L}$, range: 1-16.7 $\mathrm{mg} / \mathrm{L}$ ), $4.6 \mathrm{mg} / \mathrm{L}$ (SD: $1.8 \mathrm{mg} / \mathrm{L}$, range: $2.4-7.9 \mathrm{mg} / \mathrm{L}$ ), and 5.0 $\mathrm{mg} / \mathrm{L}$ (SD: $3.6 \mathrm{mg} / \mathrm{L}$, range: $1-12.8 \mathrm{mg} / \mathrm{L}$ ) in pregnant women in different trimesters, $13.4 \mathrm{mg} / \mathrm{L}$ (SD: $16.1 \mathrm{mg} / \mathrm{L}$, range: $1-56.3$ $\mathrm{mg} / \mathrm{L}$ ) in active and $8.8 \mathrm{mg} / \mathrm{L}$ (SD: $17.2 \mathrm{mg} / \mathrm{L}$, range: $1-73.5$ $\mathrm{mg} / \mathrm{L}$ ) in inactive IBD. No significant difference was observed between healthy pregnant and non-pregnant women $(p=0.8)$, patients with inactive IBD and non-pregnant women $(p=0.4)$, patients with inactive IBD and pregnant women ( $p=0.38$ ); however, we found that patients with active IBD have significantly higher CRP levels than pregnant women $(p<0.01)$.

\section{DISCUSSION}

In this prospective study, we aimed to confirm whether FC concentration changes during pregnancy and found that it did not 
differ between non-pregnant and pregnant women (Figure 2). Levels of inflammatory markers are commonly modified in pregnancy; however, FC and CRP may be useful indicators of relapse in IBD during pregnancy. Mechanisms such as anabolic metabolism and changes in hepatic and renal clearance result in physiological changes of laboratory parameters (6). Hemodilution can explain changes in hemoglobin and albumin levels, and these parameters may decreases with progression of pregnancy (7). Iron deficiency is also common and should not be used as a marker of blood loss (7). Erythrocyte sedimentation rate (ESR) is commonly accelerated, and physiological leukocytosis is up to 15000 cells/ $\mu \mathrm{L}$ (6). On the other hand, noninvasive techniques have great use in defining disease activity in IBD during pregnancy due to the limited use of endoscopic procedures in this population. Recently, FC is one of the most important markers of relapse, and our results confirmed that FC was significantly higher in active IBD than in healthy pregnant and non-pregnant women.

Maternal CRP level has been extensively studied as a marker of inflammation among pregnant women; however, the utility of CRP can only be assessed if effects of normal pregnancy on CRP are established. Watts et al. found no consistent changes in CRP levels with gestational age (8), although CRP level has been reported to be higher in pregnancy, even in uncomplicated cases (9). We did not find any difference in CRP levels between pregnant and non-pregnant patients. Several additional analyses have been conducted to examine the associations between CRP and pre-eclampsia/eclampsia. CRP level was higher in established pre-eclampsia than in normal pregnant women (10); furthermore, higher CRP level was reported as an independent factor of pre-eclampsia (11); therefore, it should be taken into consideration when using CRP as a biomarker.

Serum calprotectin as an indicator of systemic inflammatory response was previously evaluated in complicated pregnancies, such as those accompanied by hypertension, pre-eclampsia, and diabetes mellitus. Sugulle et al. (12) reported significant difference in median plasma calprotectin concentrations between healthy subjects and women with gestational diabetes mellitus, and serum calprotectin was elevated in pre-eclampsia as well. Serum CRP level was higher in patients with gestational diabetes than in controls. Calprotectin analysis may be more favorable from fecal samples. Jost et al. (13) assessed microbiota composition with quantitative polymerase chain reaction and pyrosequencing in healthy subjects in the pre- and post-partum period, and results demonstrated that maternal microbiota remained stable over the perinatal period with only low-grade inflammation shown by FC levels.

In recent years, a few studies assessed the utility of FC in IBD during pregnancy, most of which were not published as full papers (14-17); however, more and more data reported indicate the importance of this topic. Results are conflicted, with some showing that FC has poor diagnostic accuracy in predicting relapse (14) and no correlation being noted between FC and pMayo score and Harvey Bradshaw Index (15); however, the sensitivity and specificity of FC in determining disease activity were $81.8 \%$ and $80.7 \%$, respectively (14). In the study by Huang et al. (16) 17 pre-conception and pregnant IBD subjects were enrolled, and they found that FC concentration was higher in clinically active disease and in UC patients throughout pregnancy as well. In a prospective Israeli study (17) with over 80 samples from pregnant IBD patients, FC correlated with CDAI and pMayo score. Interestingly, CDAI score correlated weakly with ESR and CRP in the CD group; however, for those with inflammatory presentation, the correlation became more significant. Of note, the same work group previously reported on the limitation of using FC; they found no correlation between FC and clinical scores as well as between albumin levels and inflammatory serum parameters (15). The influence of pregnancy on symptoms as well as the physiological effects of pregnancy on serum parameters should also be taken into consideration when assessing clinical activity indices. Correia et al. (7) established that FC concentration did not differ during the trimesters of pregnancy; in addition, FC showed no correlation with clinical scores, albumin levels, ESR, and CRP levels.

The main limitation of this study was the low number of pregnant subjects when subdivided in trimesters; however, to our knowledge, this is the first full paper that assesses FC in healthy pregnant women. To summarize, our results revealed that FC concentration did not change during pregnancy in healthy women; by contrast, it elevated in active IBD, suggesting that FC may be a useful noninvasive marker for controlling disease activity in pregnant IBD patients, if CRP is not elevated. Nevertheless, further studies are needed to examine the prognostic role of FC and influential factors on FC in pregnant women with IBD.

Ethics Committee Approval: Ethics committee approval was received for this study from the ethics committee of University of Szeged.

Informed Consent: Written informed consent was obtained from all participants who participated in this study.

Peer-review: Externally peer-reviewed.

Author Contributions: Concept - T.M., A.B., K.F.; Design - A.B., T.M., K.F.; Supervision - T.M., A.P., A.B., K.F.; Resources - K.F., T.M., A.P., M.K.; Materials - K.F., T.M.; Data Collection and/or Processing - A.B., A.Berényi, É.P-K., Á.A., A.C., M.K., A.F., R.B, Á.M., Á.S., R.M.; Analysis and/or Interpretation A.B., M.S., T.M., Z.S., K.F.; Literature Search - A.B., R.B., M.R.; Writing Manuscript - A.B., K.F.; Critical Review - T.M., K.F., A.F.

Conflict of Interest: No conflict of interest was declared by the authors.

Financial Disclosure: This paper was supported by the János Bolyai Research Scholarship of the Hungarian Academy of Sciences (BO/00632/14/5) and by TAMOP-4.2.2.A-11/1/KONV-20120035, TAMOP-4.2.2-A-11/1/KONV-2012-0052 TAMOP-4.2.2.A-11/1/ KONV-2012-0073 and OTKA PD 105948 (PI: Dr. Klaudia Farkas). 


\section{REFERENCES}

1. Smith LA, Gaya DR. Utility of faecal calprotectin analysis in adult inflammatory bowel disease. World J Gastroenterol 2012; 18: 6782-9. [CrossRef]

2. Kostakis ID, Cholidou KG, Kallianidis K, Perrea D, Antsaklis A. The role of calprotectin in obstetrics and gynecology. Eur J Obstet Gynecol Reprod Biol 2010; 151: 3-9. [CrossRef]

3. Sato N, Isono K, Ishiwata I, Nakai M, Kami K. Tissue expression of the $\mathbf{S 1 0 0}$ protein family-related MRP8 gene in human chorionic villi by in situ hybridization techniques. Okajimas Folia Anat Jpn 1999; 76: 123-9. [CrossRef]

4. D'Haens G, Sandborn WJ, Feagan BG, et al. A review of activity indices and efficacy end points for clinical trials of medical therapy in adults with ulcerative colitis. Gastroenterology 2007; 132: 76386. [CrossRef]

5. Schroeder KW, Tremaine WJ, Ilstrup DM. Coated oral 5-aminosalicylic acid therapy for mildly to moderately active ulcerative colitis. A randomized study. N Engl J Med 1987; 317: 1625-9. [CrossRef]

6. Schulze H, Esters P, Dignass A. Review article: the management of Crohn's disease and ulcerative colitis during pregnancy and lactation. Aliment Pharmacol Ther 2014; 40: 991-1008. [CrossRef]

7. Correia LM, Bonilha DQ, Ramos JD, Ambrogini O, Miszputen SJ. Treatment of inflammatory bowel disease and pregnancy: a review of the literature. Arq Gastroenterol 2010; 47: 197-201. [CrossRef]

8. Watts DH, Krohn MA, Wener MH, Eschenbach DA. C-reactive protein in normal pregnancy. Obstet Gynecol 1991; 77: 176-80. [CrossRef]

9. Hwang HS, Kwon JY, Kim MA, Park YW, Kim YH. Maternal serum highly sensitive C-reactive protein in normal pregnancy and preeclampsia. Int J Gynaecol Obstet 2007; 98: 105-9. [CrossRef]
10. Teran E, Escudero C, Moya W, Flores M, Vallance P, Lopez-Jaramillo P. Elevated C-reactive protein and pro-inflammatory cytokines in Andean women with pre-eclampsia. Int J Gynaecol Obstet 2001; 75: 243-9. [CrossRef]

11. Qiu C, Luthy DA, Zhang C, Walsh SW, Leisenring WM, Williams MA. A prospective study of maternal serum C-reactive protein concentrations and risk of preeclampsia. Am J Hypertens 2004; 17 : 154-60. [CrossRef]

12. Sugulle M, Kvehaugen AS, Brække K, Harsem NK, Staff AC. Plasma calprotectin as inflammation marker in pregnancies complicated by diabetes mellitus and superimposed preeclampsia. Pregnancy Hypertens 2011; 1: 137-42. [CrossRef]

13. Jost T, Lacroix C, Braegger C, Chassard C. Stability of the maternal gut microbiota during late pregnancy and early lactation. Curr Microbiol 2014; 68: 419-27. [CrossRef]

14. Kanis SL, de Lima A, Van Oorschot V, Van Der Woude CJ. Su1802 Fecal Calprotectine Is a Poor Predictor of IBD Relapse During Pregnancy. Gastroenterology 2016; 150 (Suppl 1): S556. [CrossRef]

15. Shitrit ABD, Miznikov I, Adar T, Goldin E. Su1252 Limitations in Using Fecal Calprotectin As a Biomarker of IBD Disease Activity During Pregnancy. Gastroenterology 2015; 148(Suppl 1): S452. [CrossRef]

16. Huang V, Bal J, Foshaug RR, et al. Su1255 Fecal Calprotectin Is Elevated With Clinical Disease Activity During Pregnancy in Women With Inflammatory Bowel Disease. Gastroenterology 2015; 148(Suppl 1): S452. [CrossRef]

17. Schweistein $H$, Adar T, Shteingart S, et al. P135 Serum Chitinase 3-like-1 (CHI3L1) and faecal calprotectin levels for non-invasive disease activity assessment in inflammatory bowel disease patients during pregnancy. Gastroenterology 2016; 150(Suppl 1): S987.[CrossRef] 